\title{
Internationalization of higher education: excellence or network building? What do BRICS countries need most?'
}

\author{
Maxim Khomyakov* \\ Tom Dwyer** (1) \\ Wivian Weller***
}

\begin{abstract}
The article is devoted to discussing international collaboration regarding higher education in the BRICS countries. It starts with the analysis of the radical changes occurred in the global academic world, described as a joint influence of global trends towards massification, globalization and internationalization. We argue that BRICS countries can meet these challenges by means of two main approaches: through building excellence university projects and via developing horizontally structured university networks, such as the BRICS Network University. The goals of the first are creating elite universities and better integration to the global academia, while the second addresses most pressing development issues faced by BRICS' societies. The conclusion is that while excellence projects do help to develop world-class education, the networks better answer current needs of the BRICS countries.
\end{abstract}

Keywords: higher education, neo-liberal transformation of education, internationalization of higher education, BRICS Network University.

\footnotetext{
a Translated from Portuguese by Liana Fernandes, revised by the Brazilian authors.

* Higher School of Economcs, St. Petersburg \& Urals Federal University, Yekaterinburg, Russia.

** University of Campinas (Unicamp), São Paulo, Brazil.

*** University of Brasília (UnB), Brasília, Brazil.
} 


\section{Internacionalização da educação superior: excelência ou construção de redes? Do que os países do BRICS precisam mais?}

Resumo

O artigo é dedicado à discussão sobre a cooperação internacional no contexto da educação superior nos países do BRICS. Inicia com uma análise das mudanças radicais no mundo acadêmico global, que são descritas como uma influência conjunta das tendências de massificação, globalização e internacionalização. Segundo os autores, os países do BRICS podem enfrentar esses desafios a partir de duas abordagens principais: por meio da criação de vários projetos de excelência e com o desenvolvimento de redes universitárias estruturadas horizontalmente, a exemplo da BRICS Network University. Os objetivos da primeira abordagem consistem na criação de universidades de elite e de uma melhor integração à academia global, enquanto a segunda aborda questões mais prementes relacionadas ao desenvolvimento atual das sociedades nos BRICS. A conclusão é que, embora os projetos de excelência ajudem a desenvolver uma educação de classe mundial, as redes conseguem responder melhor às necessidades atuais dos países do BRICS.

Palavras-chave: educação superior, transformação neoliberal da educação, internacionalização da educação superior, BRICS Network University.

\section{Introduction: towards the development of a transnational educational capitalism}

here is a striking resemblance between most of recent discussions on
the higher education revolution we all are experiencing today. We
refer here to four main processes that constitute radical changes in the academic environment today: massification, commercialization, globalization and internationalization (Altbach; Reisberg; Rumbley, 2009). These four processes, however, are only aspects of a single global transformation, of a general trend. They are strongly interconnected and intertwined. Internationalized universities, for example, are also naturally commercialized simply because it is very difficult to convince national taxpayers to support international students. On the other hand, a growing middle class in several 
countries in the Global South seeks access to higher education abroad, thus contributing to the internationalization and massification of universities in the Global North. The four trends are in constant feedback loop, jointly contributing to the process of radical transformation.

This transformation is neoliberal in its essence, as it results in treating higher education not as an important public good, but as a product for sale (Hazelkorn, 2011; Rhoads; Li; Ilano, 2014; Dill; Soo, 2005), and this has been intensified by the increasing importance given to academic rankings. The logic of the public good has been replaced with that of commercial brands, and the Humboldtian notion of individual development gave way to educational services provided by universities. The result is a phenomenon of "educational capitalism", which threatens to wipe out non-commercial values. As commercial enterprises, universities stop performing some of their most important social functions (Sandel, 2012).

Internationalization is certainly one of the most prominent aspects of this global transformation. The explosive growth of young populations in countries like Nigeria, India, Ethiopia, Indonesia, Kenya, Philippines, Iran, Pakistan, Angola, and Nepal makes them potentially very attractive markets for recruiting foreign students. The scarcity of higher education institutions, combined with the gradual growth of the middle class, leads an increasing number of young people from these countries to seek paid education abroad. The academic neoliberal revolution further reinforces the gap between the Global South, considered a provider of students, and the Global North, the main destination for them (Wagner, 2017). The resulting commercialization of universities is blurring the boundaries between public and private education. Thus, for example, in many public universities in the United States of America, only a fifth of the budget comes from public sources (Altbach; Reisberg; Rumbley, 2009). This fact makes us wonder in what sense education in some developed countries can still be called "public".

In this understanding, internationalization and "academic radicalization" not only carry along openness and inclusion, either supposed or real, but 
also give rise to the consolidation of the global education market, the fierce competition between universities and national education systems, the replacement of nationally oriented approaches with transnational commercial education as well as the gradual disappearance of the notion of education as a public good. Consequently, universities' struggles for material and human resources are intensified both nationally and internationally. Thus, internationalization and globalization come along with the fundamental processes in the formation of the global educational capitalist system.

Most universities in the countries of the Global South end up losing this competition, regardless of how active and engaged they are in the race. Those which do not partake lose from the start; those that participate find it impossible to compete with established centers of academic power and eventually also lose. Competition for reputation leads to the so-called Matthew Effect, in which the established reputation is not contested, but simply reinforced. Pusser and Marginson describe the project of worldwide academic rankings as "neo-imperial" and argue that "because the norms of ranking systems are mostly consistent with the world's strongest higher education institutions located in the United States, this disciplinary effect is especially invidious in nation-states outside the United States" (Pusser; Marginson, 2013, p. 558). Undoubtedly, with the arrival of innovations, such as massive open online courses (MOOCs), in which millions of students take online courses at the best world-class universities, this gap between North and South becomes even wider (Zembylas; Vrasidas, 2005).

The growing gap between the Global North and Global South leads universities in emerging countries to look for an effective strategy to overcome the most deleterious differences. Presently, we would like to discuss here two of these strategies: the first is some universities' endeavor to claim their own share of the global education market through active participation in the global race for excellence, while the second is more of an attempt to build an alternative vision. The first strategy was implemented in several projects of excellence in different countries, while the second focuses on horizontal network projects. While the first strategy aims for the creation 
of world-class elite universities, the other deals with specific problems in societies of the Global South. The first one is in full agreement with the current neo-liberal transformation of global education, whereas the second one is an attempt to find an alternative to the standards promoted by transnational educational capitalism. In the next section, we shall briefly analyze the impact of each of these strategies on the national education systems of the BRICS countries ${ }^{1}$.

\section{Projects for excellence: paving the way for transnational education}

The impact of the new model of transnational higher education on national systems is particularly intense in countries struggling for better representation in the global education market. This struggle, intensified by the obsession with academic rankings, can sometimes lead to the compromising of national goals and local traditions in higher education (Khomyakov, 2016). Those who decide to actively participate in the global academic race must be ready to invest heavily in some elite institutions. On the one hand, "a world-class university is a \$1-1.5 b-a-year operation" (Hazelkorn, 2007, p. 1 ); on the other hand, building a new reputation is much more expensive than maintaining an already existing one. The most prestigious universities in the World are generally the oldest, this places countries with a recent academic tradition, when viewed by itself, at a disadvantage and also demands that they make significant investments in research infrastructure and in human capital, in other words, in the recruitment of internationally renowned teaching and research staff. In the BRICS countries China has spent close to USD 6 billion in programs dedicated to creating world-class universities (WCUs) since 1999, among which are the 985 Project and the Double First Class University Plan, there has been strong emphasis in reinforcing the qualifications of academic staff through having them spend

${ }^{1}$ In this article we will not discuss the functioning and organization of higher education in the BRICS countries. On this subject, see Carnoy et al. (2013) and Schwartzman, Pinheiro and Pillay (2015). 
long periods overseas (above all in English speaking countries), incentives for publishing in international journals, recruitment of foreign teaching and research staff for their universities and the foundation of international master's and doctoral programs that are taught in the English language ${ }^{2}$. Between 2012 and 2017, Russia invested approximately USD 878.5 million in their 5-100 Project, designed to increase the international competitiveness of the top 21 higher education institutions in the country ${ }^{3}$.

Some results of these investments in the BRICS countries have already been recognized. Research coordinated by Professor Martin Carnoy, of Stanford University, highlights that China and Russia, and to a lesser extent Brazil and India, are increasingly positioning themselves as true competitors with respect to both the quantity and the quality of the students who are trained in sciences and engineering (Carnoy et al., 2016). In spite of the investments made in courses of excellence, above all in China and Russia, the performance of the universities from the BRICS countries in the world academic rankings is still not impressive. Even China, with its high investments, had only 7 universities in the top 200 in 2019, according to the latest ranking by Times Higher Education (THE), and 8 universities in the top 200, according to QS World University Rankings, published by Quacquarelli Symonds (QS), from the UK. Russia has one university in both rankings; South Africa has two institutions in THE top 200 ranking and one in QS top 200 ranking; India and Brazil are not represented in THE top 200 ranking and have two universities each featured in QS top 200 ranking. On the other hand, incredibly, the United Kingdom is represented with 32 universities among THE top 200 ranking, and with 30 institutions in QS top 200. This contrasting world ranking clearly illustrates the gap that countries

${ }^{2}$ See, among others, Qingnian, Duanhong and Hong (2011), Ying (2011), and Peters and Besley (2018).

${ }^{3}$ See, among others, Sidorenko and Gorbatova (2015) and Khomyakov (2016). 
in emerging economies are now so desperately trying to fill through their excellence projects ${ }^{4}$.

The main objective of initiatives for excellence is to achieve better integration into the global academic domain, to the detriment of concentrating on more pressing national issues that end up being set aside. In the case of Russia, the 5-100 project is openly oriented towards improving the performance of its universities on the global stage. It initially established a totally unrealistic goal for the educational system of bringing at least five universities into the top 100 in the world ranking of universities (Khomyakov, 2016). In some cases, the objectives may be expressed in a more subtle way, but they all invariably lead to the same goal: the promotion of transnational technological education, which has become a new educational norm in late modernity. In fact, internationalization has become one of the most important goals in the development of higher education.

The most important thing here is that the universities involved in the search for a better integration into "world academia" are forced to undergo transformations in order to meet external standards. Thus, the impact of the ranking system on the configuration of an institution does not affect the "institutions at the top of the global ranking tables that can determine their own identities" (Amsler; Bolsmann, 2012, p. 287). In some emerging countries, elite national institutions have been "partly displaced" by the world's leading universities (Marginson, 2007, p. 11). The result of reacting to the ranking system can be truly disastrous for countries that strive for a better placement of their higher education systems in major ranking scores.

Another obvious feature of excellence programs is their orientation to create elite schools typical of world class universities, with different missions and purposes. Elite schools, while recruiting the best students from the best high schools, obtain additional funding. This government funding of certain elite schools contributes to further increase fundamental educational

${ }^{4}$ For an analysis of the new meanings that universities in BRICS countries might give to the notions of "excellence" and "world-class universities", see this interesting article by David and Motala (2017). 
inequalities in these societies, since most students who graduate from the best high schools belong to the upper middle class, government subsidies for excellence initiatives indirectly favor the better-off sectors of society. Excellence programs, therefore, indirectly reinforce social inequality and injustice (Tomlinson, 2008; Liu, 2016).

Evidently, excellence projects also have positive features. They make universities care about their international reputations, set high international standards and integrate research and education into world academia. Such projects encourage researchers to publish in specialized journals and motivate educators to create educational programs capable of attracting good international students. Rankings become an interesting benchmarking tool and provide university administrators with useful metrics (Hazelkorn, 2014). Without a doubt, "rankings are here to stay. Even if academics are aware that the results of rankings are biased ... they also recognize that as impressive position in the rankings can be a key factor in securing additional resources..." (Rauhvargers, 2013, p. 25).

However, the pursuit of a better integration into the so called "world academy" cannot lead to neglect of the most pressing problems in the country itself and neither to compromising the school's original mission. A unique model, based on the standards of World Class Universities situated in the developed countries, is not necessarily better and, the majority of the time, does not take into account local specificities. Therefore, it is necessary to find a suitable balance between the orientation towards international standards and national or regional commitment of the higher education institution.

\section{BRICS Network University: addressing common problems}

One possible response to the imbalances resulting from this obsession with global rankings is given by academic networks of universities with similar position and status, which share general approaches based on similar problems within their societies. This helps to understand why horizontally 
organized South-South cooperation is even more important than the traditional vertically established collaboration between the "developed" North and the "emerging" South.

The BRICS, the acronym BRIC was initially invented by Jim O'Neill in 2001, and later with South Africa's 2011 entry into the grouping, became BRICS. It was initially conceived as an economic grouping and its action was restricted to the world of finances (Stuenkel, 2015). Over the years BRICS has been building itself, above all, as a political grouping, which, in spite of the changes in governments in the respective countries over recent years and the serious economic problems that have occurred above all in Russia, Brazil and South Africa, continue to dialogue in different spheres. Its leaders meet systematically, among other occasions, during the annual summit of the BRICS leaders, which had its 11th edition in 2019 in Brasilia. The countries that form the grouping are characterized more by their differences than their similarities, but what make the group endure are some similarities and a philosophy for working together. With respect to their similarities, we highlight the fact that they are large developing countries, they play leading roles in their regions, they share common ideas about the architecture of international multilateral institutions built up after the Second World War, in other words, that these do not adequately consider the interests of developing countries. To this extent it was necessary to develop a new philosophy and new cooperative practices, which, to some extent, have concretized in the creation of the New Development Bank (NDB). "The intention was that relations of equality, mutual respect and confidence between the member countries permeate all the dimensions of the policies and operations.... Respect for national sovereignty would be of central importance" (Batista, 2019, p. 265). Given that much of the Western press criticizes the BRICS, it continues to be active and is the fruit of an extraordinary work of political will of these countries. It is the first non-regional association of developing countries since the formation of the movement of non-aligned countries after the 1955 Bandung conference. Dominique Wolton, in the introduction of a special issue of the journal 
Hermès on "BRICS: an ignored area", underlines that the grouping is "one of the most interesting terrains for studying cultural globalization, proof that politics is endless, and that the absence of legitimacy does not hinder inventivity. This improbable project continues to exist. It is the most original creation since the UN" (Wolton, 2017, p. 9).

BRICS is a group focused on establishing a more pragmatic rather than a normative consensus. BRICS' general objectives and immediate goals have always been pragmatic: overcoming the consequences of the global economic crisis, creating conditions for sustainable development, protecting national security, among other things (Stuenkel, 2015). For this reason, the creation of a common educational field was not considered, at least until this moment, as a task proper of BRICS institutions. As a result, there had not been much collaboration in research and education between BRICS countries. The number of co-publications among researchers from any peer group in the five countries does not exceed 3\% of the total number of publications from a specific BRICS nation (Khomyakov, 2016). As far as academic mobility is concerned, only China has an intense exchange of international students. Double degree partnerships between universities from different BRICS countries are also extremely rare. Furthermore, educational systems, apart from China and Russia, are quite different between countries and can hardly be compared. It was in this context that Altbach and Basset (2014, p. 2) claimed that the concept of the BRICS bloc "is actually of little relevance in understanding the complex higher education environment".

If the BRICS group is to develop and provide a truly alternative vision of "world-making", then it will contribute by conveying - beyond pure pragmatism - a message to the world, as well as approaches guided by different values. The development of any value framework, however, requires common educational and research fields, as well as rich cultural interactions between the countries. For a higher education project of the BRICS to be taken seriously, it must include all these features, otherwise, it will soon be replaced by a more viable alternative. 
Having understood this, the foundation of the BRICS project is the idea of the 'Emerging Global South', with horizontally structured collaboration as one of its inherent constructs. This idea is, in turn, based on theories of plural modernity (Wagner, 2017) and it implies a new understanding of development ${ }^{5}$. It implies the development of a non-zero-sum game based on principles of equality, autonomy and sustainability (Fan, 2016) ${ }^{6}$. In this understanding, BRICS countries are not in any way standing against the prevailing neoliberal world order, but rather trying to provide an alternative vision of development, devoid of the remnants of imperialism and colonialism ${ }^{7}$

\section{The origin of the BRICS Network University}

The strengthening of South-South relations has also been encouraged in the academic sphere of the BRICS countries. It is worthwhile underlining that the universities in the BRICS countries originated in a range of distinct academic traditions with forms of organization and functioning which are quite different when compared one with another. Moreover, the forces that govern them are linked to the political systems of each country (Carnoy et al. 2015; Schwartzman et al. 2015). Despite the asymmetries originating in the different academic traditions of these institutions, of the positions they hold in the international rankings and their interests in the academic space, the BRICS have promoted the creation of cooperative academic networks. In this direction, the BRICS Network University represents one of the most well-developed projects up until the present time. Through being run in a network, it seeks to reduce the impacts of existing asymmetries between academic institutions, to permit the establishment of a cooperative relationship in which all partners can benefit from the sharing of knowledge

${ }^{5} \mathrm{On}$ this aspect, and based on this concept, there is a research currently in progress at the BRICS Studies Center of Fudan University (Shanghai, China).

${ }^{6}$ On this subject, see Center for BRICS Studies (2015).

${ }^{7}$ Stunkel has called these efforts a hidden world of intra-BRICS cooperation which are being carried out in different areas and themes. For more details, see the list with the themes of the meetings and the frequency with which these occurred (Stunkel, 2015, chapter 5). 
in the areas relating to the strategic interests of the countries (win-win cooperation), without however, interfering in the sovereignty of the countries, in the structure of the institutions and in the functioning of their systems.

The BRICS Network University, which has been given the acronym BRICS NU, was created through a Memorandum of Understanding, signed in Moscow by the Ministers of Education of the five countries on November $18^{\text {th }}$, 2015. The BRICS NU held its first meeting on April 2016, in Yekaterinburg, Russia, with the goal of forming a networked university that will offer, among other things, masters and doctorate programs in the six fields of knowledge listed as priorities in the aforementioned Memorandum: Energy; Computer Science and Information Security; BRICS studies; Ecology and Climate Change; Water Resources and Pollution Treatment; and Economy. The programs must be offered in English and propose distance learning activities, regular classes and intensive courses (e.g.: summer or winter schools).

The BRICS NU marks the opening of a unique space for academic cooperation - quite unlike universities founded in other nations (e.g.: the European University Institute and the United Nations University) - due to not having a permanent central office, being considerably specialized and operating at an intercontinental scale. It does not have a permanent secretariat or university provost. The President is appointed annually by the country that presides the BRICS and all strategic decisions are taken collectively by the International Governing Board (IGB). The Council consists of 15 permanent members representing the universities and the Ministries of Education of the five countries. In accordance to the rules of the other BRICS bodies, all decisions are made by consensus and do not require a voting mechanism.

The network currently comprises 55 universities from the five BRICS countries, which jointly implement masters and doctoral programs in the six priority fields: Economics, Water Resources, IT, Ecology, Energy and BRICS Studies. In addition to articles published on the websites of universities that are part of the BRICS NU, the main activities are recorded 
on the institution's website ${ }^{8}$. At the national level, activities are organized by National Coordination Committees composed of representatives from each university. Significant issues are discussed in the six international thematic groups, organized in accordance to the six priority fields. In this sense, the coordination system is quite complex and consists of national and international, formal and substantial, ministerial and universities-related bodies. The complexity of the system sometimes makes the decision-making process long and difficult. There is, however, a shared understanding that this system is the only way to comply with the principles of equality and autonomy (sovereignty) of the BRICS collaboration. In other words, every effort was made to guarantee the equality and autonomy (sovereignty) of the participants in what could eventually become a sustainable collaboration of the BRICS countries at the university level.

\section{Building mutual understanding and the operation of BRICS NU: proximity and distance}

Establishing a network requires efforts beyond the organizational sphere, which concerns agreements and memoranda signed by the five countries. There is a need for understanding what each partner expects from the collaboration and what each country can offer so that the equality and autonomy of all partners is guaranteed in this South-South cooperative relationship. In this sense, the relationship between the partners and the building of mutual understanding have been developed during the annual BRICS NU meetings. According to Dwyer (2017), after a preparatory meeting that convened all the coordinators of the selected projects in Brazil, the Brazilian delegation traveled to Yekaterinburg for the first meeting of the BRICS NU in April 2016. For this meeting, South Africa sent an incomplete delegation, due to being informed late about the meeting, which was in part due to social movements in the country's universities. The Russian delegation, on the other hand, was much larger than foreseen in the original

${ }^{8} \mathrm{https}: / /$ nu-brics.ru 
agreement, which caused tensions with the governing board of the BRICS NU. The Russian delegates' motivations were very different from those of the other delegates, the priority of many of them for BRICS NU was to promote international mobility of students towards their own universities, rather than cooperating in developing joint courses. Due to national factors related to the event's organization and the participants' distinct agendas, many members of the Brazilian delegation in Yekaterinburg left without a clear understanding of how the network would work. In short, there was an unbalanced representation and an entirely different understanding of the role and structure of the BRICS NU among the five countries.

Dwyer (2017) also points out that during the second annual meeting, held in Zhengzhou, China, in July 2017, the Brazilian delegation was reduced due to the administrative and financial problems that the country was facing, and was not even accorded the status of an official delegation by the Brazilian Ministry of Education. On the other hand, the South African delegation was complete and very active. The Indian delegation, despite having changed members between meetings, was the only to represent its country fully in both meetings. As for the Chinese delegation, there was a clear division in the two meetings between members, some of whom supported a different initiative called BRICS Universities League ${ }^{9}$ and some who were committed to the BRICS NU project. The group favorable to the creation of the League wished to build a platform for international cooperation not directly linked to the Ministry of Education. The second group appeared to be composed of university professors who saw no problem in this connection to the Ministry of Education. This internal Chinese division impacted unevenly on the work of the six specialized groups.

The following year, in 2018, the meeting took place in Cape Town, South Africa. At that meeting, it was announced that some Russian universities had already started offering regular or summer/winter courses, in order

${ }^{9}$ In addition to BRICS NU, an initiative led by Russia, agreements were also signed for the creation of the BRICS Universities League, led by China. However, to date, the League has made little progress compared to the BRICS NU (see Yuyun, 2018). 
to speed up the processes and show engagement in concrete actions. The noticeable schisms in the Chinese delegation appeared to have been remedied. South Africa was fully engaged, and the BRICS NU meeting also included the participation of two of the country's ministers. Brazil, once again, sent an incomplete delegation, but this time the Ministry of Education sent a representative. In addition, a commitment was made to organize the BRICS NU meeting during the Brazilian presidency of BRICS in 2019, as well as the annual meeting of the bloc leaders ${ }^{\mathbf{1 0}}$.

Tensions within some countries resulted in fragilities in the execution of cooperation projects. For the universities that participate in the network, the challenge of communicating with and understanding the Other persists: how to coexist in an open and finite world where the Other is omnipresent, but still so distinct and inevitable? The issue of the relationship with the Other, with the obligation and the difficulty of cohabitation, is at the heart of our challenges. In other words, the question that arises is: how can we have this approximation between the partners from these countries without the risk of dissipating the group and the joint project? How do deal with the fact that technological innovation, in spite of facilitating working in a network, is unable to resolve basic problems of communication and understanding between partners?

BRICS meetings are held on a wide variety of topics and with varied actors, from the State, NGOs or the civil society. Since foundation in 2009, in subsequent years, with the notable exception of 2019, the number and variety of activities has been increasing. Working collectively is not easy due to the distinct agendas, cultural perspectives and national interests. At times, and the authors have witnessed this, an entire project may risk imploding or melting away as a result of misunderstandings, which may be interpreted as interpersonal disputes. Other times, the building of BRICS

${ }^{10}$ In 2019 the BRICS NU meeting was not held as promised. However, there were some other meetings related to higher education: the BRICS Academic Forum, organized by the Institute of Economic and Applied Research (Ipea) in September and the III BRICS Seminar on Governance organized by FGV-Rio, in October. 
initiatives seems more like a house of cards than institutional development. But these are also important results, through misunderstandings, noncommunication and conflicts dialogue can also advance. Such difficulties are to be found at the heart of building the BRICS NU. Awareness - acute amongst diplomats and others who build international initiatives - reduces the likelihood that specific failures may halt the development of a spirit of cooperation. For some readers, these questions may seem trivial, but in practice they also address one of the main difficulties in the dialogue between the BRICS countries: language.

\section{Selection and participation of Brazilian HEls in the BRICS $\mathrm{NU}$}

In line with the Memorandum of Understanding for the Establishment of the BRICS NU, the Brazilian Ministry of Education, through Ordinance no. 906 of September 2nd, 2015, established the National Coordinating Committee of the BRICS Network University. Among other duties, the Committee was responsible for determining and publicizing the general criteria and rules for the participation of Brazilian universities in the BRICS NU. This committee was apparently responsible for the preparation of the call for proposals launched by Capes on December 9th, 2015, aimed at selecting proposals from Brazilian Higher Education Institutions (HEls), which, through their Graduate Programs of excellence ${ }^{11}$, would become part of the BRICS $\mathrm{NU}^{12}$. The thematic fields described in the call for proposals correspond to the six priority fields agreed in the Memorandum of Understanding signed in Moscow on November 18th, 2015: a) Energy; b) Computer Sciences and Information Security; c) BRICS studies, in courses on International Relations, Political Sciences or Social Sciences; d) Ecology and Climate

\footnotetext{
${ }^{11}$ Graduate Programs ranked ' 6 and 7 ' by CAPES. MEC were considered to be 'excellent'. ${ }^{12}$ The announcement was made during the International Seminar "Rethinking the University Comparatively between countries: Brazil, Russia, India and China". For more information cf. $\quad<$ https://www.capes.gov.br/todas-noticias/7759-edital-para-a-consolidacao-dauniversidade-em-rede-do-brics-e-lancado-durante-seminario $>$.
} 
Change; e) Water Resources and Pollution Treatment; and f) Economics. In each field, up to two proposals from universities with high qualification and expertise related to the respective theme would be selected. The purpose was to select institutions committed to the following objectives: creating new Graduate Programs to be proposed as part of the BRICS NU; developing teaching and research activities in English, with full use of inperson and distance information technologies, including instructional and educational materials; promoting faculty and student exchange in order to encourage partnerships between HEls and research centers in the BRICS countries (MEC, 2015).

In Brazil, proposals by Graduate Programs (GP) from eight universities and one research institute were selected and became part of the BRICS $\mathrm{NU}$ as of 2016. Some of these projects were developed in partnership with more than one institution, as shown in table 1.

UFMG was the university with the largest number of approved projects, with a total of three, followed by Unicamp with two projects and the other HEIs, with one project each. Since the change of government in 2016, the Brazilian financing of the BRICS NU remained restricted to the Yekaterinburg meeting, up until the time this article was written (November 2019). The financial situation of Brazil's involvement was entirely different to that of the other four countries involved. This situation has made it difficult for the Brazilian parties to implement the proposals and to meet most established goals.

Considering the short-term goals of BRICS NU, which are to foster academic collaboration between universities in the five countries through joint research and the mobility of students and scholars, we may say that significant advances have already been made, mainly in the scope of activities carried out within the International Thematic Groups, according to reports made available by the network's member universities. These activities include, among others, the participation of Brazilian researchers 
and students in face-to-face meetings of the network, in joint research activities, distance courses and exchange missions ${ }^{13}$.

Table 1 - Proposals selected in the call for proposals MEC no. 03/2015 - BRICS

\begin{tabular}{|c|c|c|c|}
\hline $\begin{array}{c}\text { IES } \\
\text { Proponent }\end{array}$ & $\begin{array}{c}\text { HEI } \\
\text { Associated }\end{array}$ & GP & Title of the proposal \\
\hline \multicolumn{4}{|c|}{ FIELD: Computer Sciences and Information Security } \\
\hline UFMG & - & $\begin{array}{l}\text { Computer } \\
\text { Sciences }\end{array}$ & $\begin{array}{l}\text { Cyber-Physical Systems for a Massively } \\
\text { Connected Society }\end{array}$ \\
\hline UFRGS & - & Computing & $\begin{array}{l}\text { Joint Graduate Program in Cyber Security: } \\
\text { Bridging the Cyber and Physical Worlds } \\
\text { Through Smart and Secure Management }\end{array}$ \\
\hline \multicolumn{4}{|c|}{ FIELD: Ecology and Climate Change } \\
\hline INPA & - & $\begin{array}{l}\text { Biology } \\
\text { (Ecology) }\end{array}$ & INPA's proposal for the BRICS 2015 \\
\hline UFF & USP & Geochemistry & $\begin{array}{l}\text { UFF-USP South American Climate Change: } \\
\text { from the past to the future }\end{array}$ \\
\hline \multicolumn{4}{|c|}{ FIELD: Economy } \\
\hline UFMG & - & Economy & $\begin{array}{c}\text { Comparative Development: Emergent Issues in } \\
\text { BRICS Countries }\end{array}$ \\
\hline UNICAMP & UFRJ & $\begin{array}{l}\text { Economic } \\
\text { Sciences }\end{array}$ & $\begin{array}{l}\text { BRICS: Economy Challenges for a Horizontal } \\
\text { and Sustainable Alliance }\end{array}$ \\
\hline \multicolumn{4}{|c|}{ FIELD: Energy } \\
\hline UFSC & - & $\begin{array}{l}\text { Mechanical } \\
\text { Engineering }\end{array}$ & $\begin{array}{c}\text { Network University Graduate Program in } \\
\text { Energy Engineering }\end{array}$ \\
\hline UFV & - & $\begin{array}{l}\text { Agricultural } \\
\text { Engineering }\end{array}$ & $\begin{array}{l}\text { Contribution of the Federal University of } \\
\text { Viçosa to the BRICS Network University }\end{array}$ \\
\hline \multicolumn{4}{|c|}{ FIELD: BRICS Studies } \\
\hline UNICAMP & UFRJ / UFRGS & Sociology & $\begin{array}{c}\text { BRICS Sociology: Development, Inequality and } \\
\text { Dialogue }\end{array}$ \\
\hline PUC/Rio & - & $\begin{array}{l}\text { International } \\
\text { Relations }\end{array}$ & BRICS Policy Center \\
\hline \multicolumn{4}{|c|}{ FIELD: Water Resources and Population Treatments } \\
\hline UFMG & - & & $\begin{array}{l}\text { Water Resources, Sanitation and Environment } \\
\text { Management: research, education and } \\
\text { innovation in the BRICS economies }\end{array}$ \\
\hline UFRJ & - & & Water resources and environmental studies \\
\hline
\end{tabular}

Source: MEC/Capes, 2016 (compiled by the authors).

${ }^{13}$ For more information, see $<$ https://nu-brics.ru/itg $>$. 
In Brazil, we highlight the BRICS Network University meeting focused on Economics and organized by the Institute of Economics of the University of Campinas, between the 5th and the 9th of August 2019. During the event, meetings of the BRICS NU Economics steering committee took place, as well as a Research Seminar by the International Group on Economics and a Winter School for students, which included not only students from the five countries of the bloc, but also from other nations, such as Germany, Austria, United States, Guatemala, Colombia, Iran and Tajikistan ${ }^{14}$.

Regarding the research strand focused on "BRICS Studies" maintained by Unicamp and the associated universities, Federal University of Rio Grande do Sul (UFRGS) and Federal University of Rio de Janeiro (UFRJ), we highlight the contribution of the collective works Handbook of social stratification in the BRIC countries (Li, Gorshkov, Scalon, Sharma, 2013) and Handbook of the sociology of youth in BRICS countries (Dwyer, Gorshkov, Modi, Li, Mapadimeng, 2018.), which have been used in several course programs offered at universities associated with the BRICS NU. These two important sociology handbooks have a lot to teach, and here we summarize some elements worth noting. Notably, it is possible to reach a sociological understanding of our partners without going through years of specialized studies on each society. Li Peilin writes in the introduction to the handbook, of which he was the chief editor, that analyzing

changes in the social stratification structures of the BRIC countries, is a special sociological perspective (...). This very special perspective will also help us unveil the mystery of how these emerging powers, with such dramatic differences in history, geography, culture, language, religion etc., could in some instances share a common will and take joint action (Li, Gorshkov, Scalon, Sharma, 2013, p. xxiv-xxv).

This observation highlights the governance challenges, common to countries with large territories and populations, postulated long ago by Montesquieu in L'esprit des lois. The two aforementioned books show

${ }^{14}$ See < https://www.unicamp.br/unicamp/noticias/2019/08/09/unicamp-sedia-atividades-dobrics-nu $>$ e $<$ https://we.hse.ru/en/brics $>$. 
that the development of these countries does not follow the theory of modernization. Both works reveal that there are social dynamics common to some of these countries which are not always the subject of reflection in the West. Within the scope of the research strand of BRICS Studies, although under an entirely different funding situation, we have also observed the opening of the CASS-Unicamp Center for Studies on China in May 2019. CASS (Chinese Academy of Social Sciences) is China's most important research institution on social sciences and humanities. Unicamp, Brazil's leading university by some rankings, is the first Latin-American university to have such a CASS Center, which aims to provide Brazilian scholars with perspectives that should lead to the identification of the opportunities and challenges that the rise of China presents for Brazil, to promote collaboration among researchers and exchanges between Brazil and China ${ }^{15}$.

On the other hand, one middle term BRICS NU goal is to create joint graduate programs that will issue degrees valid in the five countries, has made little progress. Not only financial investments will be necessary to achieve this, but also specific agreements to enable the mutual recognition of the degrees issued by these programs. As pointed out in the article, barriers raised by the public bodies that regulate higher education in Brazil have halted the progress of academic dialogue between Brazil and the other BRICS countries in the context of BRICS NU. As for the long-term goals - to improve scientific development according to the needs of noncentral countries, with the aim of offering a contribution to "reshaping the knowledge of the world"16 - considering Brazil's current political and economic situation, marked by drastic cuts in resources for public universities and for research development agencies, the country's scientists have been set a difficult task. At present only China and Russia appear to be moving closer to achieving this goal.

\footnotetext{
${ }^{15}$ For more information, see the article on the inauguration of the Center at: < https://www. unicamp.br/unicamp/index.php/noticias/2019/05/10/unicamp-inaugura-centro-da-cassacademia-chinesa-de-ciencias-sociais $>$.

${ }^{16}$ See $<$ https://www.eco.unicamp.br/eventos/annual-meeting-of-the-brics-network-universityeconomics $>$.
} 


\section{Final remarks}

Throughout this article, we have tried to demonstrate that, in order to present themselves as a sustainable alternative, BRICS countries have attempted to create a common educational field. Joint educational projects should bring the normative dimension to the highly pragmatic BRICS bloc. In this sense, it is reasonable for the BRICS countries to take part in several excellence projects which aim to better integrate them into the global academic world, while also taking part in horizontal South-South cooperation. The first strategy is organized according to the main lines of the current academic neoliberal revolution, while the second seeks to offer alternatives to the existing power system in international higher education. Active participation in horizontal projects is undoubtedly of great interest to BRICS' higher education institutions. The BRICS NU provides an incipient example of how these projects may be implemented. The initial steps have barely been taken, and much remains to be done.

However, considering the fact that the BRIC bloc has only been institutionalized in 2009, and South Africa was only incorporated in 2011 (Stuenkel, 2015), it can be said that this child has already taken important steps with regard to South-South cooperation between universities. According to Dwyer,

when I went to Beijing in 2010, I considered the idea of a future for the BRICs to be a hypothesis. Over the past few years, I have worked to promote mutual recognition among BRICS sociologists. I learned that dialogues work best when they are based on friendship and bilateral relationships. I could never have imagined at the time that leaders, diplomats and sociologists could go so far. Life is made of bets: at the moment, my bet is that the project can work. On a personal level, I would like to continue my research on the construction of bilateral relations between Brazil and China. If these results help to think about the BRICS, I would be very happy, but as Cristovão Buarque reminds us (...) the BRICS must be a source of inspiration (Dwyer, 2017, p. 105). 
Maxim Khomyakov is Professor at the Department of Political Science and International Affairs of the HSE University and Deputy Director of the HSE campus in Saint Petersburg, Russia.

$\bowtie$ mhomyakov@hse.ru

Tom Dwyer is Professor at the Department of Sociology of the University of Campinas (UNICAMP), Brazil, he holds a CNPq research productivity scholarship.

$\triangle$ tom@unicamp.br

Wivian Weller is Associate Professor at the Faculty of Education at the University of Brasilia (UnB), Brazil, she holds a CNPq research productivity scholarship.

凶ivian@unb.br

\section{References}

1. ALTBACH, Philip G.; BASSETT, Roberta M. Nix the BRIC - at least for the higher education debate. Higher Education International, n. 77, p. 2-5, 2014. https:// doi.org/10.6017/ihe.2014.77.5671

2. ALTBACH, Philip G.; REISBERG, Liz; RUMBLEY, Laura. Trends in global higher education: tracking an academic revolution. Executive summary. A report prepared for the UNESCO 2009 World Conference on Higher Education. Paris: UNESCO, 2009.

3. AMSLER, Sarah S.; BOLSMANN, Chris. University ranking as social exclusion. British Journal of Sociology of Education, v. 33, n. 2, p. 283-301, 2012. https:// doi.org/10.1080/01425692.2011.649835

4. BATISTA, Paulo N. Jr. O Brasil não cabe no quintal de ninguém: bastidores da vida de um economista brasileiro no FMI e nos BRICS e outros textos sobre nacionalismo e nosso complexo de vira-lata. São Paulo: Leya, 2019.

5. CARNOY, Martin et al. University expansion in a changing global economy: triumph of the BRICs? Palo Alto: Stanford University Press, 2013.

6. CENTER FOR BRICS STUDIES. Win-win cooperation: new development concept for BRICS partnership. Shanghai: Fudan University, FDDI, Center for BRICS Studies, 2015.

7. DAVID, Solomon A.; MOTALA, Shireen. Can BRICS build ivory towers of excellence? Giving new meaning to world-class universities. Research in Comparative and International Education, v. 12, n. 4, p. 512-528, 2017. https:// doi.org/10.1177/1745499917740652

8. DILL, David D.; SOO, Maarja. Academic quality, league tables, and public policy: a cross-national analysis of university ranking systems. Higher Education, v. 49, n. 4, p. 495-533, 2005. https://doi.org/10.1007/s10734-004-1746-8

9. DWYER, Tom. Huit ans de travail sur les BRICS. Hermès, v. 79, p. 99-106, 2017. 
10. DWYER, Tom, GORSHKOV, Mikhail K.; MODI, Ishwar; LI Chunling; MAPADIMENG, Mokong Simon. (orgs) Handbook of the Sociology of Youth in BRICS Countries. Singapore, World Scientific, 2018.

11. FAN, Yongming. New concept for development: the logic behind emerging economies' cooperation. InBRICS, n. 2, p. 3-12, 2016.

12. HAZELKORN, Ellen. How do ranking impact on higher education? IMHE Info, December, 2007, p. 1-2, 2007.

13. HAZELKORN, Ellen. Rankings and the reshaping of higher education: the battle for world-class excellence. London: Palgrave MacMillan, 2011.

14. HAZELKORN, Ellen. The effects of rankings on student choices and institutional selection. In: JONGBLOED, Ben; VOSSENSTEYN, Hans (Eds.). Access and expansion post-massification: opportunities and barriers to further growth in higher education participation. London: Routledge, 2014, p. 107-128.

15. KHOMYAKOV, Maxim B. Building a world-class university and the role of university ranking: a Russian case. In: DOWNING, Kevin; GANOTICE, Fraide. World university rankings and the future of higher education. Hershey: IGI Global, 2016. p. 393-419.

16. LI, Peilin; GORSHKOV, Mikahil K.; SCALON, Celi; SHARMA, K. L. Handbook on social stratification in the BRIC countries: change and perspective. London: World Scientific, 2013.

17. LIU, Ye. Higher education, meritocracy and inequality in China. Berlin: Springer, 2016.

18. MARGINSON, Simon. University rankings, government and social order: managing the field of higher education according to the logic of the performative present-as-future. In: SIMONS, Maarten; OLSSEN, Mark; PETERS, Michael A. Rereading education policies: a handbook studying the policy agenda of the $21 \mathrm{st}$ century. Rotterdam: Sense Publisher, 2007.

19. MEC - Ministério da Educação. Edital no 03/2015/FNE/SASE/MEC. Contrata consultor na modalidade produto. Brasília: Ministério da Educação, 2015.

20. MEC/CAPES. Resultado final. Edital no 03/2015 - BRICS. Capes, 21 mar. 2016.

21. PETERS, Michael A.; BESLEY, Tina. China's double first-class university strategy: 双一流, Educational Philosophy and Theory, v. 50, n. 12, p. 1075-1079, 2018. https://doi.org/10.1080/00131857.2018.1438822

22. PUSSER, Brian; MARGINSON, Simon. University rankings in critical perspective. The Journal of Higher Education, v. 84, n. 4, p. 544-568, 2013.

23. QINGNIAN, Xiong; DUANHONG, Zhang; HONG, Liu. Governance reform at China's "985 Project" Universities. Chinese Education \& Society, v. 44, n. 5, p. 31-40, 2011. https://doi.org/10.2753/CED1061-1932440503 
24. RAUHVARGERS, Andrejs. Global university rankings and their impact: Report II. Brussels: European University Association, 2013.

25. RHOADS, Robert A.; LI, Shuai; ILANO, Lauren. The global quest to build world-class universities: toward a social justice agenda. New Directions for Higher Education, v. 2014, n. 168, p. 27-39, 2014. https://doi.org/10.1002/he.20111

26. SANDEL, Michael J. What money can't buy: the moral limits of markets. New York: Macmillan, 2012.

27. SCHWARTZMAN, Simon; PINHEIRO, Rômulo; PILLAY, Pundy (Eds.). Higher education in the BRICS countries: investigating the pact between higher education and society. New York: Springer, 2015.

28. SIDORENKO, Tatiana; GORBATOVA, Tatiana. Efficiency of Russian education through the scale of World University Rankings. Procedia - Social and Behavioral Sciences, v. 166, p. 464-467, 2015. https://doi.org/10.1016/j.sbspro.2014.12.555

29. STUENKEL, Oliver. The BRICS and the future of global order. Lanham: Lexington Books, 2015.

30. TOMLINSON, Sally. Gifted, talented and high ability: selection for education in a one-dimensional world. Oxford Review of Education, v. 34, n. 1, p. 59-74, 2008.

31. YING, Cheng. A reflection on the effects of the 985 Project. Chinese Education \& Society, v. 44, n. 5, p. 19-30, 2011. https://doi.org/10.2753/ CED1061-1932440502

32. YUYUN, Li. Development of Cooperation in Higher Education in BRICS Countries. Changing Societies \& Personalities. v. 2, n. 4, p. 393-405, 2018. https://doi.org/10.15826/csp.2018.2.4.053

33. WAGNER, Peter (Ed.). Moral mappings of South and North. Edinburgh: Edinburgh University Press, 2017.

34. WOLTON, Dominique. Avant-propos. Hermès, La Revue, v. 2017/3, n. 79, p. 9-12, 2017.

35. ZEMBYLAS, Michalinos; VRASIDAS, Charalambos. Globalization, information and communication technologies, and the prospect of a "global village": promises of inclusion or electronic colonization? Journal of Curriculum Studies, v. 37, n. 1, p. 65-83, 2005. https://doi.org/10.1080/0022027032000190687

Received: 10 Dec. 2019. Accepted: 08 Jan. 2020. 